Branimir Kalaš ${ }^{1}$

Ivan Milenković ${ }^{2}$

Miloš Pjanić ${ }^{3}$

Jelena Andrašić ${ }^{4}$

Nada Milenković
JEL: $\mathrm{H} 20$

DOI: $10.5937 /$ industrija45-12978

UDC: 330.354:336.2(497.11)"2006/2015"

Original Scientific Paper

\title{
The Impact of Tax Forms on Economic Growth - Evidence from Serbia
}

\author{
Article history: \\ Received:20 January 2017 \\ Sent for revision: 12 February 2017 \\ Received in revised form: 28 April 2017 \\ Accepted: 5 May 2017 \\ Available online: 1 July 2017
}

\begin{abstract}
The aim of the paper is to show the relevance of nexus between tax forms and economic growth and how they affect on gross domestic product in Serbia for the period 2006-2015. The impact is manifested through the analysis of three main tax forms: personal income tax (PIT), corporate income tax (CIT) and value-added tax (VAT) and their effect on the macroeconomic indicator as gross domestic product (GDP). The analysis is for a period of ten years in Serbia, where the regression model is constructed so that the GDP is defined as the dependent variable, while the tax forms are set as independent variables. To ensure correctly specified regression model, authors used the next test: VIF test, BP and BPG test, as well as Ramsey reset test. Results show a high degree of positive correlation between the observed variables and the positive impact of the personal income tax, corporate income tax and value-added tax on the gross domestic product, but it is only the impact of value added tax statistically significant.
\end{abstract}

Keywords: Economic Growth, Income, Tax, Serbia

\footnotetext{
${ }^{1}$ University of Novi Sad, Faculty of Economics Subotica

${ }^{2}$ University of Novi Sad, Faculty of Economics Subotica, imilenkovic@ef.uns.ac.rs

${ }^{3}$ University of Novi Sad, Faculty of Economics Subotica

${ }^{4}$ University of Novi Sad, Faculty of Economics Subotica

${ }^{5}$ University of Novi Sad, Faculty of Economics Subotica 


\section{Uticaj poreskih oblika na ekonomski rast - Primer Srbije}

Apstrakt: Cilj rada je prikazati značajnost odnosa između poreskih oblika $i$ ekonomskog rasta i kako oni utiču na bruto domaći proizvod u Srbiji za vremenski period 2006-2015. godine. Uticaj je manifestovan kroz analizu tri glavna poreska oblika: porez na dohodak građana (PIT), porez na dobit kompanija (CIT) i porez na dodatu vrednost (VAT) i njihov efekat na makroekonomski indikator: bruto domaći proizvod (GDP). Analiza je za period od deset godina u Srbiji, gde je regresioni model konstruisan tako da je BDP definisana kao zavisna varijabla, dok su poreski oblici određeni kao nezavisne varijable. Da bi se obezbedio korektan regresioni model, autori su koristili sledeće testove: VIF test, BP i BPG test, kao i Ramsey reset test. Rezultati pokazuju visok stepen pozitivne korelacije između posmatranih varijabli $i$ pozitivni uticaj poreza na dohodak građana, poreza na dobit kompanija $i$ poreza na dodatu vrednost na bruto domaći proizvod, ali je samo uticaj poreza na dodatu vrednost statistički značajan.

Ključne reči: Ekonomski rast, Dohodak, Porez, Srbija

\section{Introduction - Theoretical background}

In recent decades, tax policy has been crucial question of public debate in finance (Adkisson, Mohammed, 2012), where Clark (2007) defined a country's tax regime as a key policy instrument which may positively or negatively influence to investment. Ahmad and Sial (2016) argued that tax system plays a vital role in achieving equity, social and economic improvement in any economy. Likewise, Chigbu (2012) argued that taxation is an important instrument of government that generates revenue, which also creates fiscal goals which influence the direction of investment and timing the consumption and production of goods and services. Taxes have the main place in fiscal policy and their relevance shouldn't be ignored. Tosun and Abizadeh (2005) determine taxes as one of fiscal policy instrument and many authors researched role and impact of fiscal policy on economy (Creel et al. 2005; Romer and Romer, 2010; Baltagi et al., 2011; Alesina et al. 2012; Perotti, 2013; Bajo-Rubio, Gomez-Plana, 2015). The stable fiscal policy is a crucial precondition for economic safeness and policymakers should take care of her volatility. The significance of fiscal policy volatility has been documented by a number of papers (Fatas and Mihov, 2006; Furceri, 2007; Woo, 2009). Fatas and Mihov (2006) found that fiscal rules in form of explicitly balanced budget and spending constraints decrease fiscal policy volatility. Bernardi and Chandler (2005) define that main purpose of taxes is to finance public spending. Mankiw et al. (2009) highlight the standard theory of optimal taxation which implies that a tax system should be chosen to maximize a 
social welfare function. Also, Mitra and Stern (2003) argued that an optimal tax level and structure wouldn't damage efficiency and growth.

There are many studies which have examined the effects of taxes on economic growth (Helms, 1985; Barro, 1990; Mullen and Williams, 1994; Kneller et al. 1999; Bleaney et al. 2001; Folster and Henrekson, 2001; Holcombe and Lacombe, 2004; Pjesky 2006; Arnold, 2008; Reed, 2008; Romer and Romer, 2010; Ferede and Dahlby, 2012; Okoli et al. 2014; Hunady and Orviska, 2015; Gale et al. 2015; Etale and Biingilar, 2016). Myles (2000) defined economic growths as the basis of increased prosperity, while Kira (2013) emphasized gross domestic products as one of the determinants of country's economic growth.

In their research, Nikolić and Zubović (2013) determined maintenance of macroeconomic stabilization and high rates of economic growth as one of the main objectives in economic policy. Romer and Romer (2010) researched the impact of tax changes on economic activity and their findings indicate that tax changes have a very large effect on output. They found that an exogenous tax increase of $1 \%$ of GDP lowers real GDP by $3 \%$. These findings showed that economic growth is mostly negatively influenced by the level of the tax burden. Bird and Wilkie (2013) argued that some countries with high tax burden high growth rates while other countries with low tax burdens have low tax rates. Futher, Widmalm (2001) found that overall tax burden is negatively correlated with economic growth and personal income taxes have an especially negative effect. On the other hand, Lee and Gordon (2005) analyzed seventy countries over the period 1980-1997 and found that corporate taxes are robustly associated with lower economic growth while other taxes didn't have a statistical strongly association. Their results manifest that cut in the corporate rate of 10\% increases annual GDP growth per capita by 0.7 to $1.1 \%$. Ferede and Dahlby (2012) found that cutting the corporate rate by $10 \%$ increases the annual per capita growth rate by $1-2 \%$. Mertens and Ravn (2013) analyzed post-war tax changes in the US and they found that a $1 \%$ cut in the average personal income and corporate tax rate increases real GDP per capita by $1.4 \%$ and $0.6 \%$. Hunady and Orviska (2015) found a positive effect of corporate taxes on economic growth and have supported previous studies such as Mutascu et al. (2007), Kotlan et al. (2011). Kolahi and Noor (2016) researched the effects of VAT on the economic growth of 19 developing countries for a period of 1995-2010 and showed results that VAT has a negative effect on capital accumulation growth in the level and positive effect of VAT on the level of economic growth. Etale and Bingilar (2016) showed that corporate income tax and value added tax have significant positive impact on economic growth. Using a pool data on the 50 states between 2004 and 2010, Adkisson and Mohammed (2014) researched the relationship between state and local tax structure and growth of real per capita GDP. Omojimite and Godwin (2012) stand out that taxes 
determine the level and speed of economic growth in countries. Bhattarai (2010) concluded that OECD countries with high tax-GDP ratio generally have lower growth rates, while analysis of Arnold et al. (2011) suggests that economic growth can be increased by gradually shifting tax base towards consumption and immovable property. Their findings showed a statistical relationship between tax structure and short-term economic growth. Besley and Persson (2014) emphasize that low-income countries collect taxes between $10 \%$ and $20 \%$ of GDP, while the average for high-income countries is more like $40 \%$. Atems (2015) showed that taxes have negative short-run and long-run own state and spatial spillover effects on growth.

This paper is focused on three main tax forms in Serbia: personal income tax, corporate income tax and value added tax for the period 2006-2015. An analysis measures the impact of taxes on a gross domestic product which is a proxy for economic growth.

\section{Methodology}

This section provides the methodology adopted for the study of the impact of tax forms on economic growth in Serbia. The aim of the paper is to find out the relationship between tax indicators and macroeconomic indicator, where the gross domestic product, personal income tax, corporate income tax and value-added tax are used in the regression model.

Based on the objective, the paper looks to test the following hypothesis:

$\mathrm{H} 1$ : There is no significant impact of tax indicators and GDP

H1a: There is no significant impact of PIT on GDP

$\mathrm{H} 1 \mathrm{~b}$ : There is no significant impact of CIT on GDP

H1c: There is no significant impact of VAT on GDP

Authors have analyzed the impact of main tax forms on gross domestic product in Serbia. In the model, GDP is the dependent variable, while PIT, CIT and VAT are classified as independent variables. The database was used from Bulletin Public Finance from Ministry of Finance.

Table 1. Summary of variable definition

\begin{tabular}{|c|c|c|c|}
\hline Variables & Notation & Source & Outcome \\
\hline $\begin{array}{c}\text { Gross domestic } \\
\text { product }\end{array}$ & GDP & Bulletin of Public Finance & + \\
\hline Personal income tax & PIT & Bulletin of Public Finance & + \\
\hline Corporate income tax & CIT & Bulletin of Public Finance & + \\
\hline Value added tax & VAT & Bulletin of Public Finance & + \\
\hline
\end{tabular}

Source: Authors' review 
Kalaš B. et al.: The Impact of Tax Forms on Economic Growth - Evidence from Serbia

Model specification can be represented:

$\log G D P t=\beta_{0}+\beta_{1}(\log P I T t)+\beta_{2} \log (C / T t)+\beta_{3}(\log V A T t)+\ldots+e t$

where

GDP = gross domestic product, the dependent variable and proxy for economic growth;

PIT = personal income tax , the first independent variable;

$\mathrm{CIT}=$ corporate income tax, the second independent variable;

VAT $=$ value added tax, the third independent variable;

$\beta=$ the constant term;

$\beta B=$ the coefficient of the independent variables;

$\mathrm{e}=$ the error term of the equation.

The explanatory variables for the paper include:

- Gross domestic product is a monetary measure of the market value of final goods and services produced in a yearly period.

- Personal income tax represents the tax paid by persons who earn income, where it covers salaries, income from self-employment, income from capital, income from real estate, capital gains and other incomes.

- Company income tax represents the tax paid by the company or other legal entities which are established for profit, while profit tax base shall be the taxable income.

- Value-added tax is a general consumption tax which is calculated and paid on delivery of goods and services at all stages of production and supply of goods and services including the importation of goods.

\section{Data and results}

This paper examines the impact of PIT, CIT and VAT on GDP, using OLS technique based the statistical software program STATA 13 version. Firstly, authors show the trend of gross domestic product and tax forms in Serbia from 2006 to 2015.

Figure 1 reflects the trend of GDP measured by annual growth rate in Serbia for period 2006-2015. Observed period can be divided into pre-crisis period and period after a crisis where indicator has growing rate above 5\% in 2006 
Kalaš B. et al.: The Impact of Tax Forms on Economic Growth - Evidence from Serbia

and 2007. After that, gross domestic product decreased and this downfall is a very intensive in 2009 when it was a negatively of $3.9 \%$. Similarly, countries in the region recorded decrease of $4.5 \%$ in the same period (Filipović and Miljković, 2014). However, observed indicator records a positive trend where it was 0.6 in 2015 which is more than 2014 when it decreased by $1.8 \%$.

Figure 1. Trend of GDP growth rate in Serbia 2006-2015

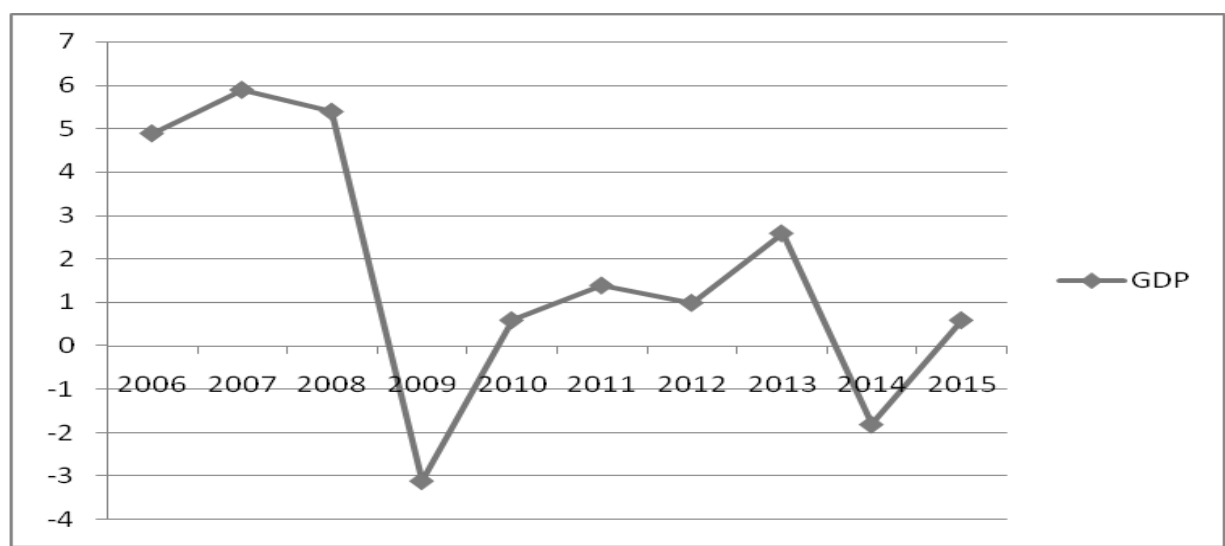

Source: Authors based on Bulletin Public Finance

Figure 2. Trend of observed tax forms in Serbia 2006-2015

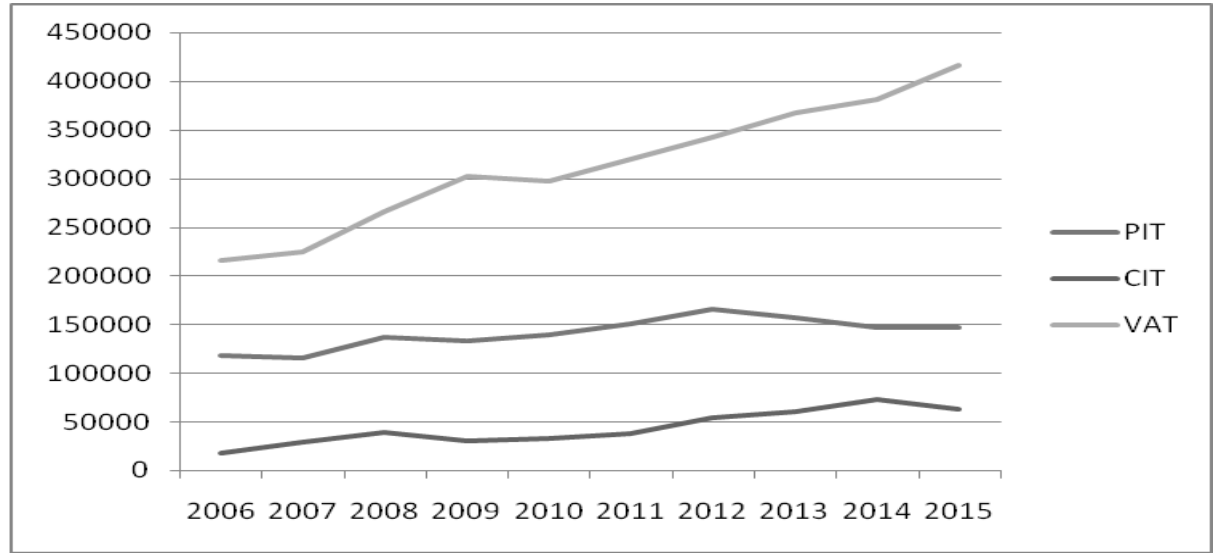

Source: Authors based on Bulletin Public Finance

Figure 2. shows the trend of absolute values of the personal income tax, corporate income tax and value-added tax in million dinars in Serbia from 2006-2015. First, personal income tax has growing trend except in 2013 and 
Kalaš B. et al.: The Impact of Tax Forms on Economic Growth - Evidence from Serbia

2014 when it recorded decrease of $5.55 \%$ and $6.15 \%$. Corporate income tax has a similar trend there it reaches the maximum level of 72744 million dinars in 2014, which is less for 10076 million dinars than the end of 2015 . Finally, it's presented value added tax which is the most generous tax form in the observed group, where it recorded increase of $92.6 \%$ in observed ten-year period.

Table 2 reflects the absolute values of the gross domestic product, personal income tax, corporate income tax and value-added tax, where the value of the dependent variable is presented in billion dinars and the value of independent variables in million dinars. In order to obtain adequate model results, their values are logarithmically.

Table 2. Data presentation and analysis

\begin{tabular}{|c|c|c|c|c|}
\hline Year & GDP & PIT & CIT & VAT \\
\hline 2006 & 2055 & 118591 & 18313 & 216007 \\
2007 & 2355 & 115772 & 29686 & 265467 \\
2008 & 2745 & 136451 & 39007 & 301689 \\
2009 & 2880 & 133482 & 31213 & 296927 \\
2010 & 3067 & 139051 & 32593 & 319369 \\
2011 & 3408 & 150824 & 37806 & 342446 \\
2012 & 3584 & 165262 & 54780 & 367472 \\
2013 & 3876 & 156085 & 60665 & 380624 \\
2014 & 3908 & 146484 & 72744 & 416056 \\
2015 & 3995 & 146775 & 62668 & \\
\hline
\end{tabular}

Source: Authors based on Bulletin Public Finance

Table 3 shows descriptive statistics of observed variables as a macroeconomic indicator (GDP) and tax indicators (PIT, CIT and VAT) in Serbia from 2006 to 2015. Authors used diagnostic tests to ensure validity and reliability of the empirical results. First, it's analyzed the presence of multicollinearity in the model by Variance Inflation Factor (VIF).

Table 3. Descriptive statistics

\begin{tabular}{l|ccccccc}
\hline Variable & Obs & Mean & Std. Dev. & Min & Max & Skewness & Kurtosis \\
\hline GDP & 10 & 3.493817 & .0984497 & 3.312812 & 3.601517 & 0.3151 & 0.7728 \\
PIT & 10 & 5.146368 & .0492633 & 5.063603 & 5.218173 & 0.4508 & 0.9150 \\
CIT & 10 & 4.609188 & .185134 & 4.26276 & 4.861797 & 0.5892 & 0.9304 \\
VAT & 10 & 5.4867 & .0945496 & 5.334468 & 5.619152 & 0.5464 & 0.6125 \\
\hline
\end{tabular}

Source: Authors' calculation based on STATA

Table 4 represents the calculation of VIF test for independent variables: personal income tax (PIT), corporate income tax (CIT) and value added tax (VAT). Using this test, authors confirm an absence of multicollinearity 
Kalaš B. et al.: The Impact of Tax Forms on Economic Growth - Evidence from Serbia between independent variables, bearing in mind that reference value of this test is 10 .

Table 4. Diagnostic Tests - VIF test

\begin{tabular}{r|rc}
\hline Variable & VIF & $1 / \mathrm{VIF}$ \\
\hline VAT & 7.15 & 0.139900 \\
CIT & 5.48 & 0.182536 \\
PIT & 3.45 & 0.290267 \\
\hline Mean VIF & 5.36 & \\
\hline
\end{tabular}

Source: Authors' calculation based on STATA

Table 5. Diagnostic Tests - BP test

\begin{tabular}{|c|c|c|}
\hline Breusch-Pagan/Cook-Weisberg & test for & chi2(1) \\
\hline
\end{tabular}

\begin{tabular}{l|l} 
heteroskedasticity & Prob $>$ chi2 $=0.5493$
\end{tabular}

Source: Authors' calculation based on STATA

Brewsch-Pagan Godfrey test was adopted in the paper and results discovered probability values of 0.5493 which exceeds $p=0.05$ and rejected the null hypothesis of heteroskedasticity residuals.

Table 6. Diagnostic Tests - BPG test

\begin{tabular}{r|c|c|c}
\hline & \multicolumn{4}{|c}{ Breusch-Godfrey Serial Correlation LM test } \\
\hline lags (p) & $\mathrm{F}$ & $\mathrm{Df}$ & Prob $>\mathrm{F}$ \\
\hline 1 & 1.291 & $(1,5)$ & 0.3074 \\
\hline
\end{tabular}

Source: Authors' calculation based on STATA

Results of the Serial Correlation Test was adopted in the study and results revealed high positive probability value of 0.3074 which exceeds $p=0.05$. This means rejection of the null hypothesis of the presence of serial correlation between observed variables.

Table 7. Ramsey Reset test - misspecification

\begin{tabular}{l|ll}
\hline Ramsey Reset test & $F(3,3)=0.64$ \\
\cline { 2 - 2 } & Prob $>\mathrm{F}=0.6368$ \\
\hline
\end{tabular}

Source: Authors' calculation based on STATA

To ensure correctly specified regression model, authors test the null hypothesis of model misspecification and results showed that there is high probability value of 0.6368 which is the above the value of $p=0.05$ and determined the positive relationship between observed variables.

The results above manifests the regression result between GDP, PIT, CIT and VAT. The R-square shows that PIT, CIT and VAT explain about $98.49 \%$ of the 
Kalaš B. et al.: The Impact of Tax Forms on Economic Growth - Evidence from Serbia

variations in GDP, where after adjusting for degree of freedom, the variables explain about $99.7 \%$ of the variations in GDP. Looking at the value of $t$ statistics, there is a positive effect of dependent variables, but it's only the impact of VAT statistically significant.

Table 8. Regression analysis of observed variables

\begin{tabular}{|c|c|c|c|c|c|c|}
\hline Source & SS & $\mathrm{Df}$ & \multicolumn{2}{|l|}{ MS } & Number of & 10 \\
\hline Model & .085911533 & 3 & \multicolumn{2}{|l|}{.028637178} & $\begin{array}{l}F(3,6) \\
=\end{array}$ & 130.22 \\
\hline Residual & .001319522 & 6 & \multicolumn{2}{|l|}{.00021992} & Prob $>F$ & 0.0000 \\
\hline Total & .087231055 & 9 & \multicolumn{2}{|l|}{.009692339} & $\begin{array}{l}\text { R-squared } \\
= \\
\text { Adj R- } \\
\text { squared = } \\
\text { Root MSE } \\
= \\
\text { Durbin- } \\
\text { Watson } \\
\text { stat } \\
=\end{array}$ & $\begin{array}{r}0.9849 \\
0.9973 \\
.01483 \\
2.347582\end{array}$ \\
\hline GDP & Coef. & Std. Err. & $T$ & $P>|t|$ & \multicolumn{2}{|c|}{ [95\% Conf. Interval] } \\
\hline PIT & .3779766 & .1862469 & 2.03 & 0.089 & .0777533 & .8337064 \\
\hline CIT & .1218122 & .0624959 & 1.95 & 0.099 & -.0311097 & .2747342 \\
\hline VAT & .6406589 & .1397794 & 4.58 & 0.004 & .296831 & .9826868 \\
\hline cons & -2.527948 & .6940771 & -3.64 & 0.011 & -4.226293 & -8.296022 \\
\hline
\end{tabular}

Source: Authors' calculation based on STATA

Table 9. Correlation matrix

\begin{tabular}{c|llll}
\hline Variable & GDP & PIT & CIT & VAT \\
\hline GDP & 1.0000 & & & \\
& 10 & & & \\
PIT & $0.8859^{*}$ & 1.0000 & & \\
& 0.0006 & & & \\
CIT & 10 & 10 & & \\
& $0.9330^{*}$ & $0.7851^{*}$ & 1.0000 & 1.0000 \\
VAT & 0.0001 & 0.0071 & & \\
& 10 & 10 & 10 & \\
& $0.9810^{*}$ & $0.8402^{*}$ & $0.9028^{*}$ & \\
& 0.0000 & 0.0028 & 0.0003 & \\
\hline
\end{tabular}

Source: Authors' calculation based on STATA

In an attempt to determine the relationship between variables, authors carried out correlation matrix and the results are presented in the table below. Table manifests the relationship between variables where results showed that there 
exist a high positive relationship between PIT, CIT and VAT with GDP. Looking at $p$-values, this positive relationship of observed variables is significant and it can conclude there is an emphasized correlation between personal income tax, corporate income tax and value added tax with gross domestic product.

\section{Conclusion}

Taxes reflects an important tool for the government and their main function is to collect funds to finance and coverage public expenditures. An adequately designed tax system with optimally defined tax types facilitates the functioning of the economy and contributes to growth. Using regression model, it's displayed a positive impact of personal income tax, corporate income tax and value-added tax on the gross domestic product. The results confirmed the hypothesis that PIT and CIT don't have a significant impact on GDP but on the other hand, VAT has a positive impact on GDP and it's a statistically significant. Similarly, the correlation matrix shows an extremely high degree of positive correlation between observed variables, which is statistically significant. This paper has a novelty and diversity which can be substantiated by the fact that there is not similar research in Serbia. Also, it' s confirmed that the personal income tax and corporate income tax don't have a statistically significant impact on GDP, as well as positive impact of value-added tax which differs from previous research in other countries. Future research will be focused on adding new variables and widening to other countries in the region to their comparative analysis.

\section{References}

Adkisson, R., \& Mohammed, M. (2012). Pragmatism to dogmatism: The laissez faire myth and the disabling of the American Fiscal Review of Social Economy, 70 (4), 421-450.

Adkisson, R., \& Mohammed, M. (2014). Tax structure and state economic growth during the Great Recession, The Social Science Journal, 51(1), 79-89, http://dx.doi.org/10.1016/j.soscii.2013.10.009 pp. 79-89.

Ahmad, S., \& Sial, M. (2016). Taxes and economic growth: An empirical analysis of Pakistan, European Journal of Business and Social Sciences, 5(2), 16-29.

Arnold, J. (2008). Do Tax Structures Affect Aggregate Economic Growth? Empirical Evidence From a Panel of OECD Countries, OECD Economic Department Working Papers, ECO/WKP(2008) 51.

Alesina, A., Favero.C, \& Giavazzi,F. (2012). The output effect of fiscal consolidations, Working Paper 18336, NBER. 
Kalaš B. et al.: The Impact of Tax Forms on Economic Growth - Evidence from Serbia

Arnold, J., Brys, B., Heady, C., Johansson, A., Schwellnus, C., \& Vartia, L. (2011). Tax policy for economic recovery and growth, Economic Journal, 121, 59-80.

Atems, B. (2015). Another look at tax policy and state economic growth: The long-run and short-run of it, Economics Letters, 127, 64-67, http://dx.doi.org/10.1016/j.econlet.2014.12.035

Bajo-Rubio, O., \& Gomez-Plana, A. (2015). Alternative strategies to reduce public deficits: Taxes vs Spending, Journal of Applied Economics, 18(1), 45-70.

Baltagi, B.H., Fingleton, B, \& Pirrote, A. (2011). Estimating and forecasting with a dynamic spatial panel data model, Oxford Bull. Econ. Stat. 0305-9049.

Barro, R. J. (1990). Government Spending in a Simple Model of Endogenous Growth, The Quarterly Journal of Economics, 98(5), 103-125.

Bhattarai, K.(2010). Taxes, public spending and economic growth in OECD countries, Problems and Perspectives in Management, 8(1),14-30.

Bernardi, L., \& Chandler, M. (2005). Tax Systems and Tax Reforms in New EU Members, Routledge Studies in the Modern World Economy, Taylor \& Francis Group, ISBN 0-415-34988-5.

Besley, T., \& Persson, T. (2014). Why Do Developing Countries Tax So Little? Journal of Economic Perspectives, 28(4), 99-120.

Bird, R. M., \& Wilkie, J. S., (2013). Designing tax policy: constraints and objectives in an open economy, eJournal of Tax Research, 11(3), 284-320.

Bleaney, M., Norman, G., \& Kneller, R., (2001). Testing the Endogenous Growth Model: Public Expenditure, Taxation and Growth over the Long Run, Canadian Journal of Economics 34(1), 36-57.

Bulletin Public Finance (2015). MInistry of Finance, Republic of Serbia, available at: http://www.mfin.gov.rs/UserFiles/File/bilten\%20javne\%20finansije/bilten-136eng\%2018032016web.pdf

Chigbu, E.E., Akujuobi, L.E., \& Appah, E. (2012). An Empirical Study on the Causality Between Economic Growth and Taxation in Nigeria, Current Research Journal of Economic Theory, 4(2), 29-38.

Clark, W.S. (2007). Tax Policy for Investment, eJournal of Tax Research, 5(2), 244265.

Creel, J., Ducoudré, B., Mathieu C., \& Sterdyniak, H. (2005). Doit-on oublier la politique budgétaire? Une analyse critique de la nouvelle théorie antikeynésienne des finances publiques. Revue de l'OFCE 92, 43-97.

Etale, L.M., \& Bingilar, P.F. (2016). The impact of company income tax and valueadded tax on economic growth: Evidence from Nigeria, European Journal of Accounting, Auditing and Finance Research, 4(7), 106-112.

Fatás, A., \& Mihov, I. (2006), The macroeconomic effects of fiscal rules in the US states, Journal of Public Economics 90(1-2) 101-117.

Ferede, E., \& Dahlby, B. (2012). The impact of tax cuts on economic growth: Evidence from the Canadian provinces, National Tax Journal, 65(3), 563-594.

Filipović, S., \& Miljković, M. (2014). Transition Economies During Global Economic Crisis: A Difference in Differences Approach, Industrija, 42(3), 23-39. DOI: 10.5937/industrija42-6944.

Folster, S., \& Henrekson, M. (2001). Growth Effects of Government Expenditure and Taxation in Rich Countries, European Economic Review 45(8), 1501-1520.

Furceri, D. (2007). Is government expenditure volatility harmful for growth? A crosscountry analysis, Fiscal Studies 28(1), 103-120. 
Kalaš B. et al.: The Impact of Tax Forms on Economic Growth - Evidence from Serbia

Gale, W., Krupkin, A., \& Rueben, K. (2015). The Relationship between Taxes and Growth: New Evidence, National Tax Journal, 68(4), 919-942.

Helms, L. J. (1985). The Effect of State and Local Taxes on Economic Growth: A Time Series Cross-Section Approach, Review of Economics and Statistics, 67(4), 574-582.

Holcombe, R.G., \& Lacombe, D.J. (2004). The Effect of State Income Taxation on Per Capita Income Growth, Public Finance Review 32(3), 292-312.

Hunady, J., \& Orviska, M. (2015). The Non-linear Effect of Corporate Taxes on Economic Growth, Timisoara Journal of Economics and Business, 8(1), 14-31, DOI: $10.1515 /$ tjeb-2015-0002.

Kira, A.R. (2013). The Factors Affecting Gross Domestic Product (GDP) in Developing Countries: The Case of Tanzania, European Journal of Business and Management, 5(4), 148-158.

Kolahi, S., \& Noor, Z. (2016). The Effect of Value Add Tax on Economic Growth and Its Sources in Developing Countries, International Journal of Economics and Finance, 8(1), 217-228.

Kotlán, I., Machová, Z., \& Janíčková, L. (2011). Vliv zdanění na dlouhodobý ekonomický růst. The effect of taxation on long-term economic growth, Politická ekonómie, 59(5), 638-658.

Lee, Y., \& Gordon, R. (2005). Tax Structure and Economic Growth, Journal of Public Economics, 89, (5), 1027-1043.

Mankiw, G., Weinzierl, M., \& Yagan, D. (2009). Optimal Taxation in Theory and Practice, Journal of Economic Perspectives, 23(4), 147-174.

Mertens, K., \& Ravn, M. (2013). The dynamic effects of personal and corporate income tax changes in the United States, American Economic Review, 103(4),1212-1247.

Mitra, P., \& Stern, N. (2003). Tax systems in transition, WB Working Paper 2947, Washington, DC: The World Bank.

Mullen, J.K., Williams, M. (1994). Marginal Tax Rates and State Economic Growth, Regional Science and Urban Economics, 24(6), 687-705.

Mutascu, M. I., Crasneac, A. O., \& Danuletiu, D. C. (2007). The Taxes Impact On the Economic Growth: The Case of European Union. MPRA Paper 6143. Retrieved from http://mpra.ub.uni-muenchen.de/6143/1/MPRA paper 6143.pdf

Myles, G. (2000). Taxation and Economic Growth, Fiscal Studies, 21(1), 141-168.

Nikolić, I., \& Zubović, J. (2013). Structural Changes in Serbian Industry during Transition, Industrija, 41(2), 67-80. DOI: 10.5937/industrija41-3884.

Okoli, M. N., Njoku, C.D., \& Kaka, G.N. (2014). Taxation and Economic Growth in Nigeria: A Granger Causality Approach, International Journal of Research in Management, Science \& Technology, 2(3), 64-80.

Omojimite, U., \& Godwin, I. (2012). Fiscal deficit and the productivity of the Nigeria tax system 1970-2010, Journal of sustainable development, 5(4), 116-125.

Perotti, R. (2013). The 'austerity myth': Gain without pain? In A. Alesina and F. Giavazzi, editors, Fiscal Policy after the Financial Crisis. Chicago, The University of Chicago Press: 307-54.

Pjesky, R. J. (2006). What Do We Know About Taxes and State Economic Development? A Replication and Extension of Five Key Studies, The Journal of Economics, 32(1), 25-40.

Reed, W. R. (2008). The Robust Relationship between Taxes and U.S. State Income Growth, National Tax Journal, 61(1), 57-80. 
Kalaš B. et al.: The Impact of Tax Forms on Economic Growth - Evidence from Serbia

Romer, C., \& Romer, D. (2010). The Macroeconomic Effects of Tax Changes: Estimated Based on a New Measure of Fiscal Schocks, American Economic Review, 100(3), 763-801.

Tosun, M.S., \& Abizadeh, S. (2005). Economic growth and tax components: An analysis of Tax changes in OECD, App. Econ, 37, 2251-2263.

Widmalm, F.(2001). Tax structure and growth: Are some taxes better than others? Public Choice, 107(3), 199-219.

Woo, J. (2009). Why do more polarized countries run more pro-cyclical fiscal policy?, Review of Economics and Statistics, 91(4), 850-870. 